\title{
Tingkat Kesukaan Kue Lapis dengan Penambahan Daun Kelor
}

\author{
Indah Sinawang Cahyani ${ }^{\mathrm{a}, 1, *}$, Alisha Deanna Hernawan ${ }^{\mathrm{a}, 2}$, Larasati $^{\mathrm{a}, 3}$, Putri Amanah \\ Sulaeman $^{\mathrm{a}, 4}$, Retnosyari Septiyani ${ }^{\mathrm{a}}$, Retty Ikawati ${ }^{\mathrm{a}}$ \\ aUniversitas Ahmad Dahlan, Jalan Pramuka No.42 Sidikan, Yogyakarta, 55161, Indonesia \\ 1indah1900070004@webmail.uad.ac.id*; alisha1900070032@webmail.uad.ac.id ${ }^{3}$ larasati1911070024@webmail.uad.ac.id; \\ ${ }^{4}$ putriamanahsulaeman1911070025@webmail.uad.ac.id \\ * penulis korespondensi
}

\begin{abstract}
Moringa leaves or moringa can be consumed but not many Indonesians consume them because the characteristics of Moringa leaves have a distinctive odor and are not liked. Moringa leaves are a local plant that contains high nutrients, but their use as food is still very low. So that the nutrients contained in Moringa leaves can be utilized by the body, it needs to be processed into foods favored by the community such as layer cakes. This practicum was conducted to determine the effect of variations in the addition of wheat flour and moringa leaf extract on the Organoleptic quality of the moringa layer cake in terms of color, taste, texture and aroma. The method used in making this moringa layer cake, among others, uses three treatments, namely $112=1: 2$ (60 g of Moringa leaves: $120 \mathrm{~g}$ of wheat flour), $122=2: 2$ (120 g of Moringa leaves: $120 \mathrm{~g}$ of wheat flour), and $213=2: 3$ (120 g of Moringa leaves: $180 \mathrm{~g}$ of wheat flour). The results of this experiment show different Organoleptic results in each treatment and the most preferred moringa layer cake is made from a $122=2: 2$ variation $(120 \mathrm{~g}$ of Moringa leaves: $120 \mathrm{~g}$ of wheat flour)
\end{abstract}

Keywords: Moringa leaves, moringa layer cake, wheat flour

\section{ABSTRAK}

Daun kelor memiliki karakteristik yaitu bau yang khas sehingga tidak disukai. Daun kelor merupakan tanaman lokal yang mengandung zat gizi yang tinggi, namun pemanfaatannya sebagai bahan pangan masih sangat rendah. Agar zat gizi yang terkandung dalam daun kelor dapat dimanfaatkan tubuh, maka perlu diolah menjadi makanan yang digemari oleh masyarakat seperti kue lapis. Penelitian ini dilakukan untuk mengetahui pengaruh variasi penambahan ekstrak daun kelor terhadap kualitas sensoris kue lapis moringa baik dari segi warna, rasa, tekstur, dan aroma. Perbandingan penambahan daun kelor diantaranya 1:2 (60 gram daun kelor:120 gram terigu), 1:1 (120 gram daun kelor:120 gram terigu), dan 2:3 (120 gram daun kelor:180 gram terigu). Kue lapis yang diperoleh selanjutnya dinilai tingkat kesukaannya. Kue lapis dengan penambahan kelor yang berbeda memberikan penilaian atribut sensoris serta tingkat kesukaan yang berbeda. Kue lapis dengan perbandingan 1:1 (120 gram daun kelor:120 gram terigu) merupakan kue lapis yang paling disukai.

Kata Kunci: daun kelor, kue lapis moringa, tepung terigu

\section{Pendahuluan}

Di Indonesia, terdapat tanaman yang mengandung banyak manfaat bagi kesehatan masyarakat dan mengandung zat gizi yang sangat tinggi mulai dari zat gizi makro hingga zat gizi. Salah satu manfaat yang dapat diambil dari pohon kelor terdapat pada daunnya (Kouevi, 2013). Hasil penelitian Fuglie (2001) menyatakan bahwa daun kelor memiliki berbagai kandungan nutrisi yang bermanfaat. Kandungan yang paling diunggulkan pada tanaman ini 
yaitu protein, vitamin A ( $\beta$-karoten), dan zat besinya yang tinggi sehingga bagus untuk dikonsumsi dan dapat memenuhi kebutuhan gizi terutama pada kelompok rawan (Madukwe, et al., 2013; Jonni, 2008; Krisnadi, 2010; Kurniasih, 2013). Tidak hanya itu, daun kelor juga mengandung berbagai macam asam amino di mana hal ini jarang sekali ditemui pada sayuran (Kasolo, 2010).

Daun kelor dapat dikonsumsi oleh manusia, namun belum banyak masyarakat Indonesia yang mengonsumsinya dikarenakan karakteristik daun kelor memiliki bau yang khas dan tidak disukai. Di daerah pedesaan, konsumsi daun kelor hanya sebatas pada olahan sayuran berkuah seperti sayur bening dan lalapan saja. Daun kelor belum banyak diolah sebagai pangan fungsional. Oleh karena itu, perlu adanya inovasi dalam mengolah daun kelor menjadi suatu produk yang dapat diterima masyarakat agar kandungan nutrisi dalam daun kelor dapat dimanfaatkan oleh tubuh. Inovasi yang pernah dikembangkan diantaranya biskuit (Aina, 2014) dan yoghurt (Diantoro dkk, 2015).

Kue lapis merupakan kudapan yang banyak disukai masyarakat karena rasanya yang enak dengan aneka variasi taburan, tekstunya empuk, cara membuatnya yang mudah, bahan-bahan yang mudah didapat di pasaran dan harganya yang terjangkau sehinggan semua kalangan bisa membelinya. Kudapan tersebut memiliki potensi pengembangan dengan nilai fungsionalitas sehingga berpotensi untuk dilakukan substitusi kelor pada proses pembuatan kue lapis. Kandungan protein, vitamin A ( $\beta$-karoten), dan zat besi yang tinggi menyebabkan daun kelor bagus untuk dikonsumsi dan dapat memenuhi kebutuhan gizi terutama pada kelompok rawan (Madukwe, et al., 2013).

Tujuan penelitian ini untuk mengetahui potensi daun kelor sebagai bahan substitusi pada kue lapis dan mengetahui pengaruh penambahan daun kelor terhadap kualitas sensoris kue lapis baik dari segi warna, rasa, tekstur, dan aroma kue lapis.

\section{Metode Penelitian}

\subsection{Bahan}

Bahan yang digunakan dalam pembuatan kue lapis dengan penambahan daun kelor antara lain terigu, daun kelor, susu, telur, vanili, gula pasir, garam, ragi instan, dan baking powder. Bahan yang digunakan diperoleh dari pasara tradisional dan took bahan kue.

Peralatan yang digunakan untuk membuat kue lapis moringa antara lain panci pengukus, timbangan, baskom, kain saring, sendok atau pengaduk, kompor, blender, mixer, dan loyang kue. Peralatan yang digunakan untuk uji organoleptik antara lain lembar kuisioner dan alat tulis.

\subsection{Prosedur Penelitian}

Penelitian ini menggunakan Rancangan Percobaan Blok Acak Lengkap (Randomized Complete Block Design) yang terdiri dari 3 taraf perlakuan yaitu pembuatan kue lapis dengan penambahan daun kelor degngan perbandingan 1:2 (60 g daun kelor : $120 \mathrm{~g}$ terigu), 1:1 (120 g daun kelor : $120 \mathrm{~g}$ terigu), dan 2:3 (120 g daun kelor : $180 \mathrm{~g}$ terigu).

Pembuatan kue lapis dengan penambahan daun kelor dimulai dengan blanching daun kelor selama 3 menit kemudian pendinginan. Daun kelor dihaluskan menggunakan blender dengan penambahan minyak goreng dan krimer kental manis hingga halus. Secara terpisah, telur dan 
gula dicampur menggunakan mixer hingga kental berjejak. Campuran terigu, vanili, dan baking powder ditambahkan sedikit demi sedikit sambil diayak dan penambahan terigu dilakukan secara bergantian dengan campuran jus kelor sesuai perlakuan yang diamati (60 g daun kelor : $120 \mathrm{~g}$ terigu [1:2], $120 \mathrm{~g}$ daun kelor : $120 \mathrm{~g}$ terigu [1:1], dan $120 \mathrm{~g}$ daun kelor : $180 \mathrm{~g}$ terigu [2:3]). Pengadukan adonan dilakukan dengan spatula hingga rata dengan teknik aduk balik. Setelah adonan tercampur rata, adonan dituangkan ke loyang dan dikukus hingga matang (pengecekan dengan tes tusuk).

\subsection{Metode Analisis}

Evaluasi pengaruh penambahan daun kelor menggunakan uji deskripsi untuk parameter warna, tekstur, rasa, dan aroma serta uji kesukaan keseluruhan menggunakan panelis sebanyak 30 orang.

\section{Hasil dan Pembahasan}

Perbandingan daun kelor dan terigu yang berbeda memberikan pengaruh terhadap sensoris kue lapis dengan penambahan daun kelor, baik pada parameter warna, tekstur, rasa, aroma maupun kesukaan keseluruhan.

Tabel 3.1 Hasil Uji Organoleptic Kue Lapis dengan Penambahan Daun Kelor

\begin{tabular}{|c|c|c|c|c|}
\hline Parameter & $\mathrm{A}(1: 2)$ & B (1:1) & $\mathrm{C}(2: 3)$ & Keterangan \\
\hline Warna & 1,4 & 1,5 & 1,4 & $\begin{array}{l}\text { 1. Putih susu } \\
\text { 2. Putih agak kuning } \\
\text { 3. Putih kehijauan } \\
\text { 4. hijau } \\
\text { 5. army }\end{array}$ \\
\hline Tekstur & 5 & 3 & 1 & $\begin{array}{l}\text { 1. bantet } \\
\text { 2. agak bantet } \\
\text { 3. sedikit bantet } \\
\text { 4. lembut } \\
\text { 5. lembut kokoh }\end{array}$ \\
\hline Aroma & 3 & 4 & 3 & $\begin{array}{l}\text { 1. Sangat tajam } \\
\text { 2. Tajam } \\
\text { 3. Agak tajam } \\
\text { 4. Tidak tajam } \\
\text { 5. Sangat tidak tajam }\end{array}$ \\
\hline Rasa & 3 & 3 & 2 & $\begin{array}{l}\text { 1. Sangat manis } \\
\text { 2. Manis } \\
\text { 3. Gurih manis } \\
\text { 4. Agak gurih manis } \\
\text { 5. Gurih kurang manis }\end{array}$ \\
\hline
\end{tabular}

\subsection{Warna}


Warna yang disukai oleh panelis yaitu perbandingan 1:1 (120 g daun kelor : $120 \mathrm{~g}$ terigu), warna yang dihasilkan yaitu warna hijau cerah sedangkan warna yang dihasilkan oleh perbandingan 1:2 (60 g daun kelor : $120 \mathrm{~g}$ terigu) dan 2:3 (120 g daun kelor : $180 \mathrm{~g}$ terigu) adalah hijau pucat dan hijau kecoklatan. Perbedaan warna tersebut dikarenakan jumlah terigu yang digunakan (Tabel 3.1). Terigu mengandung karbohidrat yang tinggi, sehingga pada saat pemanggangan karbohidrat akan mengalami proses browning atau pencoklatan karena karbohidrat terutama glukosa dan fruktosa akan kehilangan air dan menghasilkan glukosa dan fruktosa dengan warna coklat hingga kehitaman (Nataliningsih, 2005).

Semakin tinggi konsentrasi tepung terigu maka proses pencoklatan akan semakin cepat terjadi sehingga pada perbandingan 1:2 (60 g daun kelor : $120 \mathrm{~g}$ terigu) dan 2:3 (120 g daun kelor : $180 \mathrm{~g}$ terigu) akan menghasilkan warna yang lebih pucat dan lebih coklat dibandingkan dengan perbandingan 1:1 (120 g daun kelor : $120 \mathrm{~g}$ terigu).

\subsection{Rasa}

Rasa yang paling disukai adalah kue lapis dengan perbandingan 1:2 (60 g daun kelor : 120 $\mathrm{g}$ terigu). Perbandingan 2:3 (120 g daun kelor : $180 \mathrm{~g}$ terigu) menghasilkan rasa daun kelor yang kurang mencolok dan kurang manis. Hal tersebut disebabkan oleh adanya perbedaan penggunaan terigu yang lebih banyak sedangkan penggunaan gula yang sama disetiap perbandingan. Konsentrasi gula mempengaruhi rasa yang ditimbulkan terhadap kue lapis. Menurut Kartika dkk (1988) rasa suatu bahan pangan merupakan hasil kerjasama beberapa indera antara lain indera penglihatan, pembauan, pendengaran dan perabahan. Rasa merupakan faktor yang menentukan tingkat kesukaan konsumen terhadap produk pangan. Atribut rasa yang terbentuk meliputi manis, asam, asin, dan pahit.

\subsection{Tekstur}

Tekstur makanan merupakan suatu hal yang berkaitan dengan struktur makanan yang dapat didetektif dengan baik, yaitu merasakan makanan di dalam mulut. Sifat yang digambarkan dari tekstur makanan antara lain renyah, lembut, kasar, halus, berserat, empuk, keras, bantat, dan kenyal (Puckett, 2004). Tekstur yang paling disukai adalah kue lapis dengan perbandingan 1:2 (60 g daun kelor : $120 \mathrm{~g}$ terigu) sedangkan perbandingan 2:3 (120 g daun kelor : $180 \mathrm{~g}$ terigu) menghasilkan tekstur yang bantat sehingga tidak disukai oleh panelis.

\subsection{Aroma}

Aroma kue lapis yang disukai adalah perbandingan 1:1 (120 g daun kelor : $120 \mathrm{~g}$ terigu). Perbandingan ini menggunakan ekstrak daun kelor yang lebih banyak sehingga diperoleh aroma yang sesuai. Aroma khas daun kelor mengandung senyawa volatil yang dapat menguap kerena pemanasan baik itu pengukusan maupun pemanggangan.

\subsection{Kesukaan Keseluruhan}


Hasil pengujian kesukaan total (Hedonic Test) (Tabel 3.2) menunjukkan pengaruh nyata antara perlakuan. Nilai kesukaan berkisar antara tidak suka $(2,9)$ sampai suka $(3,9)$. Uji DMRT 5\% menunjukkan bahwa kue lapis dengan penambahan daun kelor perbandingan 1:2 (60 g daun kelor : $120 \mathrm{~g}$ terigu) tidak ada perbedaan nyata dengan kue lapis perbandingan 1:1 (120 g daun kelor : $120 \mathrm{~g}$ terigu), sedangkan agak disukai oleh panelis yaitu kue lapis perbandingan 2:3 (120 $\mathrm{g}$ daun kelor : $180 \mathrm{~g}$ terigu).

Tabel 3.2 Hasil Uji Kesukaan Kue Lapis dengan Penambahan Daun Kelor

\begin{tabular}{ccccl}
\hline Tipe Uji & A (112) & B (122) & C (213) & \multicolumn{1}{c}{ Keterangan } \\
\hline Kesukaan Total & $3.9^{\mathrm{a}}$ & $3.6^{\mathrm{a}}$ & $2.9^{\mathrm{b}}$ & 1. Sangat tidak suka \\
& & & 2. Tidak suka \\
& & 3. Agak suka \\
& & 4. Suka \\
& & & 5. Suka sekali \\
& & & 6. Sangat suka sekali \\
\hline
\end{tabular}

\section{Kesimpulan}

Penambahan daun kelor pada pembuatan kue lapis dengan penambahan daun kelor memberikan pengaruh terhadap sifat organoleptic berupa warna, tekstur, aroma dan rasa. Kue lapis dengan penambahan daun kelor yang disukai adalah kue lapis dengan perbandingan 1:2 (60 g daun kelor : $120 \mathrm{~g}$ terigu) untuk parameter tekstur dan perbandingan 1:1 (120 g daun kelor : $120 \mathrm{~g}$ terigu) untuk parameter rasa dan aroma. Kue lapis dengan perbandingan 1:1 (120 gram daun kelor:120 gram terigu) merupakan kue lapis yang paling disukai.

\section{Pustaka}

Aina, Q. 2014. Pengaruh Penambahan Tepung Daun Kelor (Moringa Oleifera) dan Jenis Lemak Terhadap Hasil Jadi Rich Biskuit. E-Journal Boga. Vol 003, No 3: Surabaya Diantoro, A., Rohman,M., Budiarti, R., \& Palupi, H. T. 2015. "Pengaruh Penambahan Ekstrak Daun Kelor (Moringa Oleiera L.) Terhadap Kualitas Yoghurt", dalam Jurnal teknologi pangan, 6(2),no. 1: 59-66.

Fuglie, L.G. 2001. The Miracle Tree: The Multiple Attributes of Moringa. CTA. Netherland. 172 hal.

Jonni, M. S. 2008. Cegah Manultrisi dengan Kelor. Penerbit kanisius: Yogyakarta. Kartika, dkk. 1988. Pedoman Uji Inderawi Bahan Pangan. Yogyakarta: UGM.

Kasolo, J.N., Bimenya G.S., Ojok, L., Ochieng, J. and Jasper W.O., 2010, Phytochemicals and uses of Moringa oleifera leaves in uganda rural communities, J Med Plant Res; 4(9): 753-757

Kouevi, K.K. (2013). A Study on Moringa oleifera leaves as a supplement to West African Weaning Foods, Hamburg: University of Aplied Science

Krisnadi. 2010. Kelor Super Nutrisi. Pusat Informasi dan Pengembangan Tanaman Kelor 
Indonesia. Blora.

Kurniasih, E. 2013. Khasiat dan Manfaat Daun Kelor, penerbit pustaka baru press: Yogyakarta..

Madukwe, E., Ugwuoke, A. \& Ezeugwu, J. (2013). Effectiveness Of Dry Moringa Oleifera Leave Powder In Treatment Of Anemia. Academic Journals, 5(5), 226-228. Diakses dari www. academicjournals.org/

Nataliningsih, (2005), Analisis Kandungan Gizi dan Sifat Organoleptik Terhadap Cookies Bekatul, Jurnal Fakultas Pertanian. Universitas Bandung Raya: Bandung Puckett, R.P. 2004. Food Service Manual for Health Care Institutions. 